\title{
Auditory steady state response in hearing assessment in infants with cytomegalovirus
}

\author{
Resposta auditiva de estado estável na avaliação auditiva em lactentes com citomegalovírus \\ Importancia de lainclusión de larespuesta auditiva de estado estable en la evaluación auditiva en \\ lactantes concitomegalovirus
}

Daniela Polo C. Silva ${ }^{1}$, Priscila Suman Lopez ${ }^{1}$, Jair Cortez Montovani

\section{ABSTRACT}

Objective: To report an infant with congenital cytomegalovirus and progressive sensorineural hearing loss, who was assessed by three methods of hearing evaluation.

Case description: In the first audiometry, at four months of age, the infant showed abnormal response in Otoacoustic Emissions and normal Auditory Brainstem Response (ABR), with electrophysiological threshold in $30 \mathrm{dBnHL}$, in both ears. With six months of age, he showed bilateral absence of the ABR at $100 \mathrm{dBnHL}$. The behavioral observational audiometry was impaired due to the delay in neuropsychomotor development. At eight months of age, he was submitted to Auditory Steady State Response (ASSR) and the thresholds were 50, 70, absent in 110 and in $100 \mathrm{~dB}$, respectively for $500,1,000$, 2,000 and $4,000 \mathrm{~Hz}$ in the right ear, and $70,90,90$ and absent in $100 \mathrm{~dB}$, respectively for 500, 1,000, 2,000 and $4,000 \mathrm{~Hz}$ in the left ear.

Comments: In the first evaluation, the infant had abnormal Otoacoustic Emission and normal ABR, which became altered at six months of age. The hearing loss severity could be identified only by the ASSR, which allowed the best procedure for hearing aids adaptation. The case description highlights the importance of the hearing status follow-up for children with congenital cytomegalovirus.

Key-words: cytomegalovirus; infant; hearing loss.

\section{RESUMO}

Objetivo: Relatar o caso de um lactente com citomegalovírus congênito e disacusia neurossensorial progressiva, analisado por três métodos de avaliação auditiva.

Descrição do caso: Na primeira avaliação auditiva, aos quatro meses de idade, o lactente apresentou ausência de Emissões Otoacústicas (EOA) e Potencial Evocado Auditivo de Tronco Encefálico (PEATE) dentro dos padrões de normalidade para a faixa etária, com limiar eletrofisiológico em 30dBnHL, bilateralmente. Com seis meses, apresentou ausência de PEATE bilateral em 100dBnHL. A avaliação comportamental da audição mostrou-se prejudicada devido ao atraso no desenvolvimento neuropsicomotor. Aos oito meses, foi submetido ao exame de Resposta Auditiva de Estado Estável (RAEE) e os limiares encontrados foram 50, 70, ausente em 110 e em $100 \mathrm{~dB}$, respectivamente para 500, 1.000, 2.000 e $4.000 \mathrm{~Hz}$ à direita, e 70, 90, 90 e ausente em $100 \mathrm{~dB}$, respectivamente para 500, 1.000, 2.000 e $4.000 \mathrm{~Hz}$, à esquerda.

Comentários: Na primeira avaliação, o lactente apresentou alteração auditiva no exame de EOA e PEATE normal, que passou a ser alterado aos seis meses de idade. A intensidade da perda auditiva só pôde ser identificada pelo exame de RAEE, permitindo estabelecer a melhor conduta na adaptação de aparelho de amplificação sonora individual. Ressalta-se a importância do acompanhamento audiológico para crianças com CMV congênito.

Palavras-chave: citomegalovírus; lactente; perda auditiva.
Instituição: Departamento de Oftalmologia, Otorrinolaringologia e Cirurgia de Cabeça e Pescoço da Faculdade de Medicina de Botucatu da Universidade Estadual Paulista "Júlio de Mesquita Filho" (Unesp), Botucatu, SP, Brasil

${ }^{1}$ Faculdade de Medicina de Botucatu da Unesp, Botucatu, SP, Brasil
Endereço para correspondência:

Daniela Polo C. Silva

Distrito de Rubião Junior, s/n

CEP 18618-970 - Botucatu/SP

E-mail: daniela-polo@uol.com.br

Conflito de interesse: nada a declarar

Aprovado em: 12/5/2013 


\section{RESUMEN}

Objetivo: Relatar el caso de un lactante con citomegalovirus congénito y disacusianeurosensorial progresiva, analizado por tres métodos de evaluación auditiva.

Descripción del caso: En la primera evaluación auditiva, a los cuatro meses de edad, el lactante presentó ausencia de Emisiones Otoacústicas (EOA) y Potencial Evocado Auditivo de Tronco Encefálico (PEATE) dentro de los estándares de normalidad para la franja de edad, con umbral electrofisiológico en $30 \mathrm{dBnHL}$, bilateralmente. Con seis meses, presentó ausencia de PEATE bilateral en 100dBnHL. La evaluación comportamental de la audición se mostró perjudicada debido al retardo en el desarrollo neuropsicomotor. A los ocho meses, fue sometido al examen de Respuesta Auditiva de Estado Estable (RAEE) y los umbrales encontrados fueron 50,70 , ausente en 110 y en $100 \mathrm{~dB}$, respectivamente para $500,1.000,2.000$ y $4.000 \mathrm{~Hz}$, a la derecha, y $70,90,90$ y ausente en $100 \mathrm{~dB}$, respectivamente para 500, 1.000, 2.000 y 4.000 , a la izquierda.

Comentarios: En la primera evaluación, el lactante presentó alteración auditiva en el examen de EOA y PEATE normal, que pasó a ser alterado a los seis meses de edad. La intensidad de la pérdida auditiva solo puede identificarse por el examen de RAEE, permitiendo establecer la mejor conducta en la adaptación de aparato de amplificación sonora individual. Se subraya la importancia del seguimiento audiológico para niños con CMV congénito.

Palabras clave: citomegalovirus; lactante; pérdida auditiva.

\section{Introduction}

Congenital infection with cytomegalovirus (CMV) is a risk factor for hearing loss ${ }^{(1)}$. In the study of Kenneson and $\mathrm{Cannon}^{(2)}$, the prevalence of newborns with congenital $\mathrm{CMV}$ infection was $0.64 \%$. It is considered the most common fetal viral infection and the main cause of non-genetic sensorineural hearing loss ${ }^{(2-4)}$.

About $90 \%$ of infected infants are asymptomatic at birth, while the remaining $10 \%$ had clinical changes such as microcephaly, motor disorder, mental retardation, and hearing $\operatorname{loss}^{(5)}$. Deafness, however, is generally reported late, which makes it difficult for early identification through newborn hearing screening programmes (NHSP).

The hearing tests in neonatology are performed mainly by examination of otoacoustic emissions (OAE) and evoked auditory brainstem response (ABR), which assess, respectively, the outer hair cells in the cochlea, and neural conduction of sound ${ }^{(6,7)}$. However, the click-ABR, commonly used, allows knowing the possible hearing changes in the regions from 2,000 to $4,000 \mathrm{~Hz}$, but not at low frequencies ${ }^{(6)}$.

Still in the field of Pediatric Audiology, there is another evoked auditory response exam, the Auditory Steady State Response (ASSR) which, although little known and used, is helpful in providing accurate estimates of the frequencyspecific hearing thresholds in both ears simultaneously, including at low frequencies ${ }^{(8-10)}$. The ASSRs are the electrical responses of the brain that may be evoked by sinusoidally amplitude-modulated tones and/or modulated frequency ${ }^{(11)}$. The thresholds are obtained by statistical criteria, which makes them more objective than those found by $\mathrm{ABR}^{(12)}$.

Thus, the objective of this report was to emphasize the sequential auditory evaluation through electrophysiological measurements, and to demonstrate the importance of including the ASSR in the audiological test battery in an infant with congenital CMV and progressive sensorineural hearing loss.

\section{Case Description}

The study was developed at theSchool of Medicine of Botucatu from Universidade Estadual Paulista "Júlio de Mesquita Filho" (Unesp), after approval by the Research Ethics Committee of the institution. Parents authorized the publication of the results, having signed the informed consent.

Infant, male, born at term, already diagnosed with congenital CMV at the prenatal examination. He showed large cystic mass occupying both cerebral hemispheres, with communication to the lateral ventricles through a wide slit. Computed tomography of the brain showed remnants of right and left temporal lobe. The electroencephalogram, performed at 6 months, was compatible with focal epilepsy with diffuse involvement of the brain bioelectrogenesis, suggesting structural changes in the central nervous system. A delay was observed in the neuropsychomotor development. The patient was referred for audiologic evaluation after discharge, at 4 months of age. The following tests were conducted: Transient otoacoustic emissions (TOAE), distortion product otoacoustic emissions (DPOAE), ABR, and ASSR.

For TOAE and DPOAE tests, the equipment OtoRead/ Interacoustics was used, which allows the recording of responses by introducing a probe, with coupled microphone, in the external auditory canal. We used the parameter pass/ 
fail as criterion of analysis, described in the protocol of the equipment itself.

We conducted the research of $A B R$ through the equipment Eclipse EP-15/Interacoustics, in a quiet environment, with the infant comfortably accommodated in the lap of parents during natural sleep. We analyzed the responses of $A B R$ through the values of absolute latencies of waves I, III, and V and interpeak latencies I-III, III-V, and I-V, as well as the electrophysiological threshold testing.

For ASSR, we used the equipment CHATR-EP 200/ Otometrics, investigating the frequencies of 500, 1,000, 2,000 and $4,000 \mathrm{~Hz}$, respectively modulated at $97,81,95$ and $88 \mathrm{~Hz}$, in the right, and $92,77,84$ and $85 \mathrm{~Hz}$, in the left, with dichotic presentation. Intensity of $60 \mathrm{dBNPS}$ with increments of 10dBNPS in the search for minimum response level.

Possible changes in the middle ear were discarded by ENT assessment and acoustic impedance tests, which showed type A curve in both ears.

Because TOAEs and DPOAEs were absent in both ears at the first evaluation, the ABR was performed at 6 months of age, which showed absolute and interpeak latencies I-III, III-V, and I-V appropriate for age, and electrophysiological threshold in $30 \mathrm{dBnHL}$, bilaterally. After these tests, the infant was then monitored every 2 months: at 8 months, on a new assessment by ABR, hearing impairment was observed, featuring progressive hearing loss, with no response in both ears at $100 \mathrm{dBnHL}$. In this occasion, behavioral assessment of hearing was performed, with difficult interpretation of responses due to motor impairment of the patient, which was then submitted to the examination of the ASSR. The thresholds found were 50,70, absent in 110 and in $100 \mathrm{~dB}$, respectively for $500,1,000,2,000$ and $4,000 \mathrm{~Hz}$, on the right ear, and 70, 90, 90 and absent $100 \mathrm{~dB}$, respectively for 500 , $1,000,2,000$ and $4,000 \mathrm{~Hz}$,on the left ear, with descending curve on both ears (Figure 1).

\section{Discussion}

Deafness has a profound impact on the child's overall development. The identification and treatment are essential in the quality of life of children and their families ${ }^{(13,14)}$.

In the case of congenital CMV infection, the newborn hearing screening programs are faulty in detecting deafness in about half the cases, since hearing loss may manifest later ${ }^{(15)}$. Tode Vries et al ${ }^{(15)}$, an antiviral treatment should be used to prevent hearing impairment in newborns who have neurological symptoms. However, the authors did not report use of these drugs in cases of hearing loss. In this case, as there was no knowledge of manifestation of hearing loss in the first month due to late referral at 4 months, the benefits of this treatment regarding dysacusis were harmed.

The TOAE and DPOAE exams were not performed in the first evaluation, which justifies the hearing evaluation

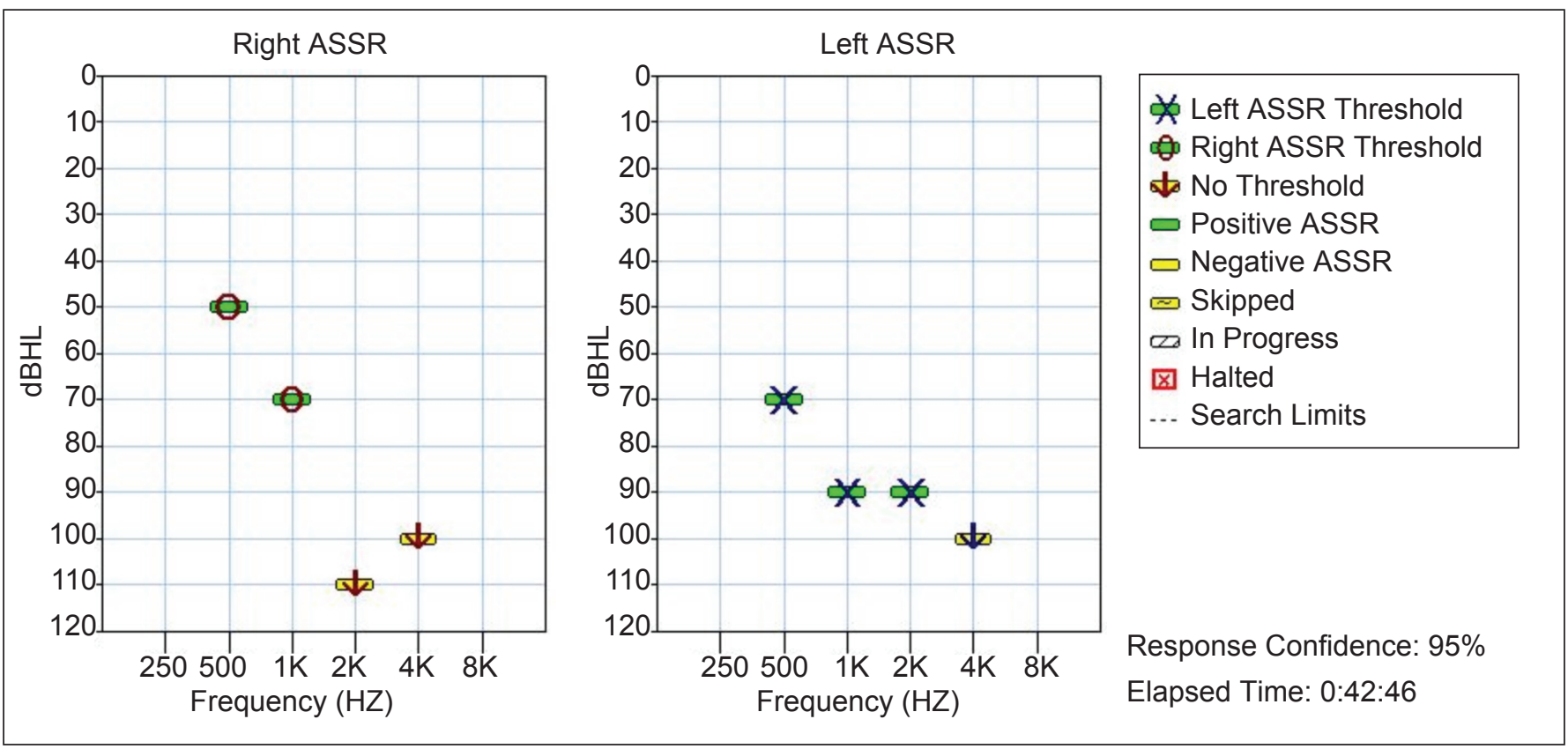

Figure 1 - Hearing thresholds, of both ears, obtained from the examination of auditory steady state response. We used the equipment CHATR-EP 200/Otometrics 
through ABR and ASSR tests, as in the case described. The monitoring of hearing every 2 months was important because it was possible to observe the progression of hearing loss with the ABR, which became non responsive at maximum intensity at 6 months old and, at 8 months, hearing impairment at the ASSR was detected. While the ABR searches only the frequencies from 2,000 to $4,000 \mathrm{~Hz}$, ASSR may be used as a complementary test to assess hearing in children incases of absence of response on theABR, complementing the findings at higher frequencies, with larger number of frequencies tests and in a shorter time $e^{(16,17)}$.

It is note worthy in this patient the fact that hearing thresholds from ASSR enabled to show the degree and configuration of hearing loss with the presence of residual hearing, which may assist in the adaption of equipment and/or hearing implants (Figure 1). This exam, while detecting the auditory thresholds, is objective and improves the understanding of behavioral responses, especially low sounds, by the child in the first year of life ${ }^{(17)}$. Thus, the ASSR is important for the diagnosis and treatment of hearing deficits, especially in preterm infants with congenital infection, with

\section{References}

1. American Academy of Pediatrics, Joint Committee on Infant Hearing. Year 2007 position statement: principles and guidelines for early hearing detection and intervention programs. Pediatrics 2007;120:898-921.

2. Kenneson A, Cannon MJ. Review and meta-analysis of the epidemiology of congenital cytomegalovirus (CMV) infection. Rev Med Virol 2007;17:253-76.

3. Nance WE, Lim BG, Dodson KM. Importance of congenital cytomegalovirus infections as a cause for pre-lingual hearing loss. J Clin Virol 2006;35:221-5.

4. Samileh N, Ahmad S, Mohammad F, Framarz M, Azardokht T, Jomeht E. Role of cytomegalovirus in sensorineural hearing loss of children: a case-control study Tehran, Iran. Int J Pediatr Otorhinolaryngol 2008;72:203-8.

5. Foulon I, Naessens A, Foulon W, Casteels A, Gordts F. A 10-year prospective study of sensorineural hearing loss in children with congenital cytomegalovirus infection. J Pediatr 2008;153:84-8.

6. Azevedo MF. Emissões otoacústicas. In: Figueiredo MS, editor. Conhecimentos essenciais para entender bem: emissões otoacústicas e BERA. São José dos Campos: Pulso Editorial; 2003. p. 35-83.

7. Durante AS, Carvalho RM, da Costa FS, Soares JC. Characteristics of transient evoked otoacoustic emission in newborn hearing screening program. Pro fono 2005; 17:133-40.

8. Lins OG, Picton TW. Auditory steady-state responses to multiple simultaneous stimuli. Electroencephalogr Clin Neurophysiol 1995;96:420-32.

9. Rance G, Tomlin D. Maturation of auditory steady-state responses in normal babies. Ear Hear 2006;27:20-9.

10. Alaerts J, Luts H, Van Dun B, Desloovere C, Wouters J. Latencies of potential risk for deafness and motors disorders. It should be emphasized that the examination complements but does not replace the OAEs and theABRs.

Therefore, the sequential assessment with these three tests is important because, as reported in the first evaluation, $\mathrm{OAE}$ were absent, and $\mathrm{ABR}$, present; in the second evaluation at 6 months of age, both $\mathrm{OAE}$ and $\mathrm{ABR}$ were absent. However, the configuration of hearing loss can only be identified through examination of ASSR, showing residual hearing in low frequencies, below $2,000 \mathrm{~Hz}$, which is not detected by the OAE and ABR tests. These findings help to establish the best approach in the adaption of an individual hearing device and to reinforce the importance of audiologic sequential monitoring in children with congenital CMV, including the ASSR in hearing research.

\section{Acknowledgements}

We thank the patients, their parents, and the institutions involved, for the support and contribution to this study.

auditory steady-state responses recorded in early infancy. Audiol Neurootol 2010;15:116-27

11. Picton TW, John MS, Dimitrijevic A, Purcell D. Human auditory steady-state responses. Int J Audiol 2003;42:117-219.

12. Johnson TA, Brown CJ. Threshold prediction using the auditory steady-state response and the tone burst auditory brain stem response: a within-subject comparison. Ear Hear 2005;26:559-76.

13. Yoshinaga-Itano C, Sedey AL, Coulter DK, Mehl AL. Language of early-and later-identified children with hearing loss. Pediatrics 1998;102:1161-71.

14. Weber BA, DiefendorfA. Triagem auditiva neonatal. In: Musiek FE, Rintelmann WF, editors. Perspectivas atuais em avaliação auditiva. Barueri: Manole; 2001. p. 323-39.

15. De Vries JJ, Vossen AC, Kroes AC, van der Zeijst BA. Implementing neonatal screening for congenital cytomegalovirus: addressing the deafness of policy makers. Rev Med Virol 2011;21:54-61.

16. Rance G, Dowell RC, Rickards FW, Berr DE, Clark GM. Steady-state evoked potential and behavorial hearing threshold in a group of children with absent click-evoked auditory brain stem response. Ear Hear 1998;19: 48-61.

17. Ribeiro FM, Carvallo RM, Marcoux AM. Auditory steady-state evoked responses for preterm and term neonates. Audiol Neurootol 2010;15:97-110. 